\title{
Bosnian Language
}

National Cancer Institute

\section{Source}

National Cancer Institute. Bosnian Language. NCI Thesaurus. Code C153863.

An Indo-European, Balto-Slavic variety of Serbo-Croatian spoken mainly by the Bosniak ethnic group of Bosnia and Herzegovina. 